\title{
A navel stone mimicking a urachal sinus
}

\author{
Hidehiko Nakano, ${ }^{1}$ Takashi Watari, ${ }^{1}$ Yu Suganami, ${ }^{1}$ Yasuharu Tokuda ${ }^{2}$
}

${ }^{1}$ Shonan Kamakura General Hospital, Kamakura City, Kanagawa, Japan

${ }^{2}$ General Internal Medicine, Tsukuba University, Mito, Ibaraki, Japan

\section{Correspondence to} Professor Yasuharu Tokuda, yasuharu.tokuda@gmail.com

\section{DESCRIPTION}

Anyone can experience finding a navel lint in one's own navel, but how does it become big?

A navel lint, also called navel fluff, belly button lint or belly button fluff, consists of cloth-like fluffy fibres mixed with cutaneous scales, fat or protein. ${ }^{1}$ Several case reports indicate that a navel lint could cause omphalitis or even sepsis. ${ }^{2} 3$

A 96-year-old woman presented with a 2-week history of recurrent fever and loss of appetite. A diagnosis of urinary tract infection was made based on the presence of pyuria and bacteriuria. However, we incidentally noticed a hard, smooth and well moving palpable mass just under the navel on abdominal examination. There was no redness, tenderness or crusting of the periumbilical skin. While examining the mass, a part of it looked like a navel stone was protruding from the navel.

An abdominal CT scan demonstrated a round, calcified high-density mass behind the navel (figure 1). The radiologist suggested the possibility of the urachal sinus, which is a congenital remains of the urachus. We removed it by soaking in sterilised olive oil. The mass was easily removed from the umbilical cavity (video 1). The pathological finding showed

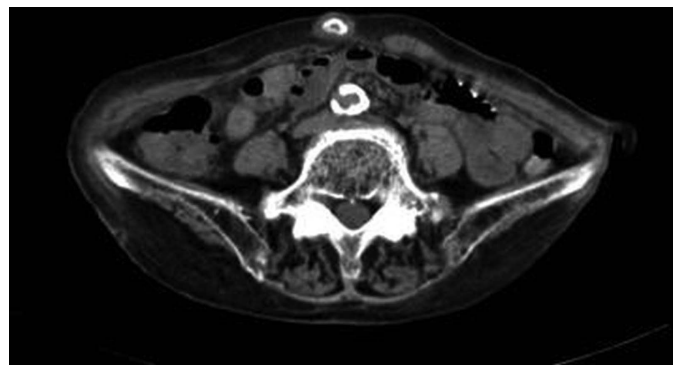

Figure 1 Abdominal CT scan show a round-shaped mass behind the navel.

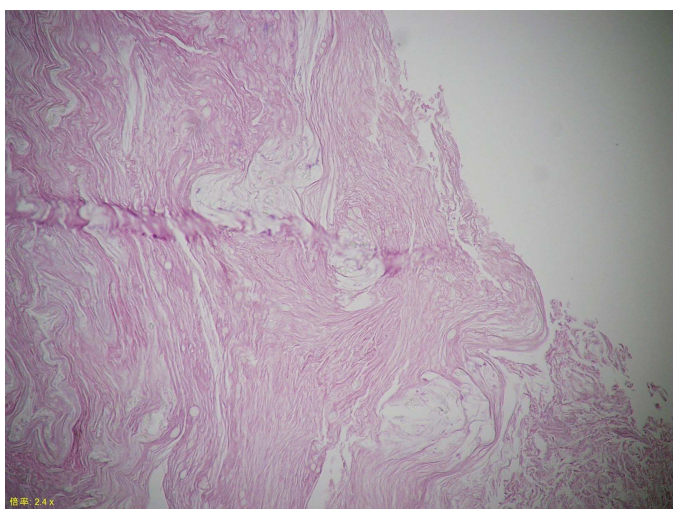

Figure 2 The microscopic image show nodular tissue composed of lamellar horny materials.

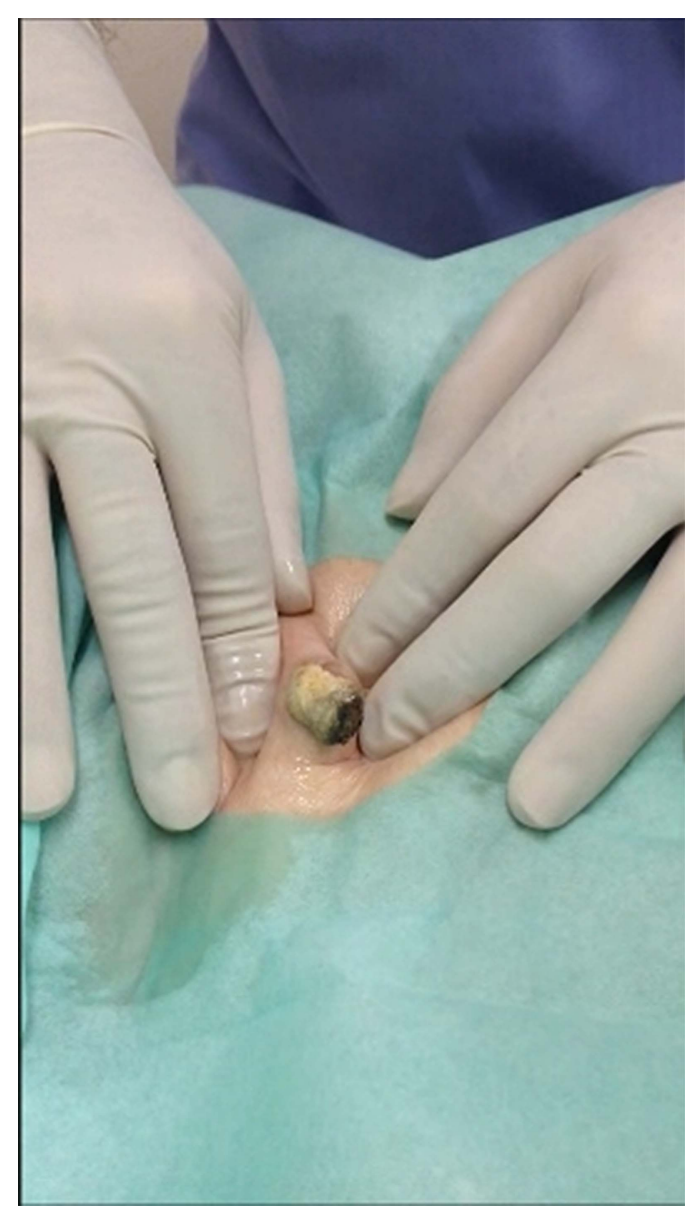

Video 1 The removal of the mass from the umbilical cavity.

nodular tissue composed of lamellar horny materials with focal microcalcification (figure 2).

\section{Learning points}

- Big navel stone could mimic urachal sinus.

- Navel lint usually does no harm, but its removal may be advised since it could sometimes cause omphalitis or even sepsis.

- A navel stone can be removed easily by soaking it in sterilised olive oil.

Acknowledgements The authors thank Dr Izumi Kitagawa for his valuable support for our work.

Contributors HN, TW and YS cared for the patient. TW and YT wrote and edited the manuscript.

Competing interests None.

Patient consent Obtained.

Provenance and peer review Not commissioned; externally peer reviewed. 


\section{REFERENCES}

1 Steinhauser G. The nature of navel fluff. Med Hypotheses 2009;72: $623-5$.
2 Sarma DP, Teruya B. 'Lint ball' omphalitis, a rare cause of umbilical discharge in an adult woman: a case report. Cases J 2009;2:7785.

3 Sroujieh AS, Dawoud A. Umbilical sepsis. Br J Surg 1989;76:687-8.

Copyright 2014 BMJ Publishing Group. All rights reserved. For permission to reuse any of this content visit http://group.bmj.com/group/rights-licensing/permissions.

BMJ Case Report Fellows may re-use this article for personal use and teaching without any further permission.

Become a Fellow of BMJ Case Reports today and you can:

Submit as many cases as you like

- Enjoy fast sympathetic peer review and rapid publication of accepted articles

- Access all the published articles

- Re-use any of the published material for personal use and teaching without further permission

For information on Institutional Fellowships contact consortiasales@bmjgroup.com

Visit casereports.bmj.com for more articles like this and to become a Fellow 